\title{
Host-ectoparasite Specificity in a Small Mammal Community in an Area of Atlantic Rain Forest (Ilha Grande, State of Rio de Janeiro), Southeastern Brazil
}

\author{
Emerson Brum Bittencourt/ ${ }^{+}$, Carlos Frederico Duarte Rocha*/++
}

\begin{abstract}
Laboratório de Ixodides, Departamento de Entomologia, Instituto Oswaldo Cruz-Fiocruz, Av. Brasil 4365, 21045-900
Rio de Janeiro, RJ, Brasil *Laboratório de Ecologia de Vertebrados, Setor de Ecologia, Universidade do Estado do Rio de Janeiro, Rio de Janeiro, RJ, Brasil
\end{abstract}

The analyses of the ectoparasite species associated with a small mammal community on Ilha Grande, a coastal island in southern of the state of Rio de Janeiro, Brazil, evaluated the level of host-ectoparasite specificity. Was used the Jaccard index for qualitative data to analyse the similarity. The lowest value of similarity occurred between Proechimys iheringi and Marmosops incanus and between Sciurus aestuans and Nectomys squamipes $\left(C_{j}=0.08\right)$ and the highest between $\mathrm{P}$. iheringi and Oxymycterus $s p .\left(C_{j}=0.33\right)$. This index showed a low value of similarity across the ectoparasite community. The only exception from this pattern of high host specificity occurred with $\mathrm{P}$. iheringi and Oxymycterus $s p$., which shared five species of ectoparasites. The similarity values, for most of the cases, is smaller than 0.2 .

Key words: host-parasite specificity - small mammals - parasitism - ectoparasites - Atlantic Rainforest - Rio de Janeiro - Brazil

Two strategies of host selection can be recognized in the relationship between ectoparasites and their small mammal hosts: (i) extreme specificity by the ectoparasite for a certain kind of host, and (ii) the absence of such a specificity. However, different ectoparasite species may show intermediate strategies (Timm 1983). Some ectoparasitic mites of the subfamily Laelapinae (Acari: Laelapidae) have been shown to be markedly host-specific to certain neotropical small mammal species (e.g. Furman 1972, Gettinger 1987, 1992b, Martins-Hatano et al. 2002). Gigantolaelaps Fonseca, 1939 and Laelaps Koch, 1836 occurring in association with a small mammal community in Central Brazil were completely host-specific, each ectoparasite species infesting only one particular host species (Gettinger 1987, 1992b). The author (Gettinger $1992 \mathrm{a}, \mathrm{b})$ also showed that Laelaps populations infesting different host species, when closely examined, were morphologically distinct, but cryptic species. Similarly, within sucking lice species (Anoplura), extreme specificity has been suggested to be the most frequent strategy

This study was made as part of the Ecology, Conservation and Management Program of Brazilian Southeast Ecosystems and of the Brazilian Southeast Vertebrates Project (Vertebrate Ecology Laboratory), both of the Setor de Ecologia of the Instituto de Biologia Roberto Alcântara Gomes of the Universidade do Estado do Rio de Janeiro.

${ }^{+}$Corresponding author. Fax: +55-21-3590.3545. E-mail: ebbittencourt@ig.com.br

Graduate fellowship Capes (Master) and CNPq (process 142.140/01-5)

${ }^{++}$Research fellow CNPq (process 300 814/94-3)

Prociência Grant from Universidade do Estado do Rio de Janeiro Received 19 November 2002

Accepted 10 July 2003
(Durden \& Musser 1994a). It has been suggested that ectoparasite-host interactions may be so specific that they can be used as an additional tool for the taxonomic identification of the host (Linardi 1977) and may even be indicative of common philogenetic lines (Barker 1994). However, the specificity of ectoparasites may also be related to microhabitat selection by the hosts, and as a result, when habitats are disturbed and the composition of the small mammal community changes, ectoparasites may encounter different hosts near their nest microhabitats, and transfer may occur (Gettinger \& Ernest 1995). Bossi (1996) suggested that the occurrence of a particular ectoparasite species living on more than one host species may be related to the behaviour, intra and interspecific relationships, and with the microhabitats utilized by the host. The second strategy, where ectoparasite species parasitize a large number of small mammal species is common with ticks. Klompen et al. (1996) suggested that these ectoparasites usually occupy a particular habitat and as a result tend to parasite a wide range of hosts living in that particular habitat.

In many species of fleas (Order Siphonaptera) exchange among hosts is common (e.g. Linardi 1977, Botelho \& Linardi 1980, 1996, Cerqueira \& Linardi 1981). Linardi and Guimarães (2000), based on the study of Holland (1964), classified the hosts of fleas into four groups: primitive (those who introduce the flea species into a certain area), primary (those who are more frequently parasitized and that maintain the local infection), secondary (those that can act in the maintenance and survival of a given Siphonaptera species) and, accidental (accidents, casual occurrences or laboratory contamination).

Despite the recognized medical and veterinary importance, studies on ectoparasites and small mammals in Brazil rarely offer an ecological view of the hostectoparasite relationship. Even so, the available studies indicate the existence of a diverse fauna of ectoparasites, and emphasize their narrow adaptation to Brazilian hosts 
(e.g. Linardi et al. 1984, 1987, 1991b, c, Guitton et al. 1986, Gettinger 1987, Gettinger \& Ernest 1995, Barros-Battesti et al. 1998).

In the present study was analysed the ectoparasite species associated with a small mammal community on Ilha Grande, evaluating the level of host-ectoparasite specificity. Was adressed the following questions: (i) what ectoparasite species are associated with each small mammal host? (ii) in which extent is the occurrence of the ectoparasite relatively specific? (iii) how similar are hosts in terms of their composition of ectoparasite species?

\section{MATERIALS AND METHODS}

Study area - The study was carried out in four areas of the Atlantic rainforest surrounding the Vila Dois Rios Village $\left(23^{\circ} 11^{\prime} \mathrm{S}, 44^{\circ} 12^{\prime} \mathrm{W}\right)$, on Ilha Grande, a coastal island in southern of the state of Rio de Janeiro, located approximately $150 \mathrm{~km}$ south of the city of Rio de Janeiro, in Southeastern Brazil. Ilha Grande is covered by Atlantic Rainforest with different levels of regeneration due to disturbances caused by human activities through the last centuries, but which ceased with the transformation of the area into a State Park (Araújo \& Oliveira 1988). Some remnants of primary forest, where only selective cutting was carried out, can still be found in the most unaccessible central areas of the island. Annual rainfall in the area is about $2200 \mathrm{~mm}$ (Estação Meteorológica, Central Nuclear de Angra dos Reis - Nuclen 1996-1999) and mean annual temperature is about $23^{\circ} \mathrm{C}$.

Collecting methods and analysis - Small mammals were trapped from March 1996 throughout April 1997 in one area of primary forest (Jararaca), two of secondary forests (Caxadaço and Mãe D'água) and in the anthropic area of Village Dois Rios. At each area were established grids of 70 live traps (Young and Sherman) which were set along 10 parallel transects ( $200 \mathrm{~m}$ long each one) in an area of 2 ha with each trap $20 \mathrm{~m}$ apart, totaling 7474 trap/nights. The traps were baited with banana and remained opened from afternoon until the next morning when they were checked for the presence of small mammals.

Each animal captured was marked (to avoid sampling the same individual) with ear-perforation code. To prevent contamination of ectoparasites between different host individuals, each individual host was anesthetized inside an individual plastic bag containing a piece of cotton soaked with sulfuric ether. The body surface of the captured small mammals was systematically checked and ectoparasites removed by combing through the pelage with the aid of a fine-tooth comb.

The ectoparasites found in each particular host were preserved in $70 \%$ ethyl alcohol, stored in host individual vials, and later identified.

To analyse the similarity of the ectoparasite community associated with different small mammal host species, was used the Jaccard index for qualitative data (Magurran 1988): $C_{j}=j /(a+b-j)$, in which $j$ is the number of the ectoparasites species occuring on both species of hosts, $a$ is the number of the ectoparasites species found on the first host species, and $b$ is the number of the ectoparasites species found on the second host species being compared.
The convention of the ecological terms in parasitology (Bush et al. 1997) was used to calculated mean abundance (MA). To assure independence of observations in the analysis, we sampled ectoparasites from each host only once (at first capture).

\section{RESULTS}

Considering all of the sampled areas, were found ectoparasites in five rodents species [Sciuridae - Sciurus aestuans Thomas, 1901, $\mathrm{n}=13$; Sigmodontinae - Oryzomys russatus (Wagner, 1848), $\mathrm{n}=3$; Oxymycterus $\mathrm{sp}$. Waterhouse, 1837, $\mathrm{n}=4$; Nectomys squamipes (Brants, 1827), $\mathrm{n}=2$ and Echimyidae - Proechimys iheringi Thomas, $1911, \mathrm{n}=35$ ] and two marsupials species [Didelphidae Didelphis aurita Wied, 1826, $\mathrm{n}=6$ and Marmosops incanus (Lund, 1846), $\mathrm{n}=4$ ]. The identification of the ectoparasite material collected from the small mammals resulted in a total of 27 identified ectoparasite taxa: Acari, Acariformes: Cheyletidae Leach, 1815 and Listrophoridae Canestrini, 1892; Acari, Parasitiformes: Macronyssidae Oudemans, 1936; Amblyomma sp. Koch 1844; Ixodes sp. Latreille, 1795; Ixodes didelphidis Fonseca \& Aragão, 1952; Tur sp. Baker \& Wharton, 1952; Tur turki Fonseca, 1959; Gigantolaelaps goyanensis Fonseca, 1939; Gigantolaelaps oudemansi Fonseca, 1939; Laelaps manguinhosi Fonseca, 1936; Androlaelaps fahrenholzi (Berlese, 1911) and Androlaelaps marmosops MartinsHatano, Gettinger \& Bergallo, 2001; Insecta, Amblycera: Gliricola porcelli (Schrank, 1781) and Gyropus lineatus Neumann, 1912; Insecta, Anoplura: Polyplax spinulosa (Burmeister, 1839); Pterophthirus wernecki Guimarães, 1950 and Hoplopleura sciuricola Ferris, 1921; Insecta, Siphonaptera: Craneopsylla minerva minerva (Rothschild, 1903); Hechtiella lakoi (Guimarães, 1948); Polygenis (Polygenis) roberti roberti (Rothschild, 1905); Polygenis (Polygenis) occidentalis occidentalis (Cunha, 1914); Polygenis (Polygenis) rimatus (Jordan, 1932); Polygenis (Polygenis) tripus (Jordan, 1933) and Polygenis (Neopolygenis) pradoi (Wagner, 1937) and Insecta, Coleoptera: Amblyopinus sp. Solsky, 1875 and Amblyopinodes sp. Seevers, 1955. Table I shows the ectoparasites recorded from each respective host.

Table II summarizes the similarity between different hosts species.

\section{DISCUSSION}

In most Neotropical ectoparasite studies the similarity of the host-parasite fauna is presented simply as a list or table of the shared ectoparasite species (e. g. Botelho \& Williams 1980, Linardi et al. 1984, 1987, 1991a, b, 1996, Guitton et al. 1986). But in a few cases, ecological coefficients have been used to explain the associations and preferential hosts (Botelho et al. 1981, Barros-Battesti et al. 1998) or numeric analyses to cluster hosts (Lareschi 1996) and these studies have begun to clarify the level of the host-ectoparasite association (i.e. specificity/ generalization).

Our data suggests that a variety of association strategies are being utilized by ectoparasites collected at Ilha Grande. On one hand, there are the species of mites, fleas and lice which occurred with high frequency and 


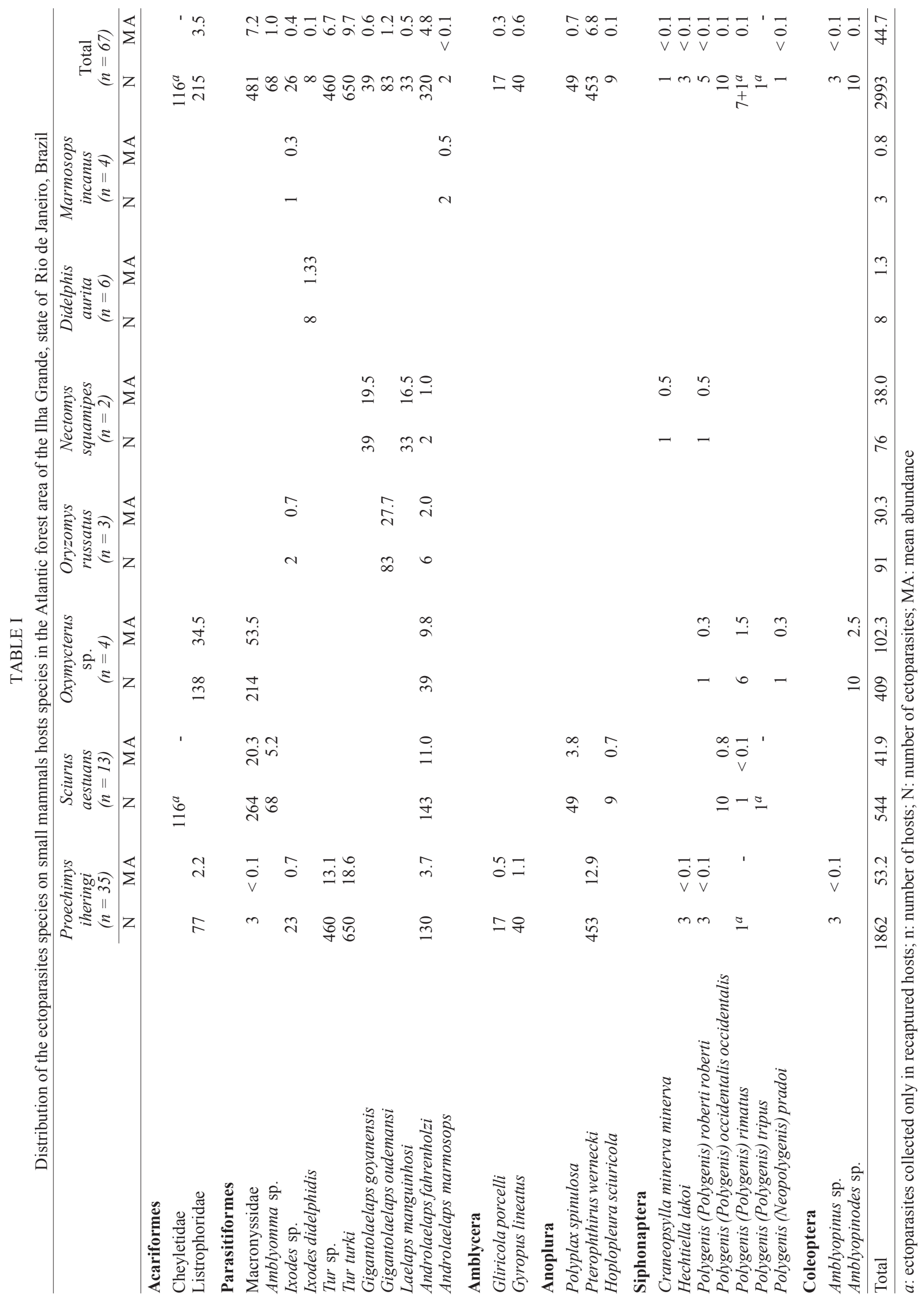


TABLE II

Jaccard quantitative index of similarity value among the associated ectoparasites species on different small mammals species of the Atlantic forest area of the Ilha Grande, state of Rio de Janeiro, Brazil

\begin{tabular}{|c|c|c|c|c|c|c|}
\hline & $\begin{array}{c}\text { Proechimys } \\
\text { iheringi }\end{array}$ & $\begin{array}{l}\text { Sciurus } \\
\text { aestuans }\end{array}$ & Oxymycterus sp. & $\begin{array}{c}\text { Oryzomys } \\
\text { russatus }\end{array}$ & $\begin{array}{l}\text { Nectomys } \\
\text { squamipes }\end{array}$ & $\begin{array}{l}\text { Didelphis } \\
\text { aurita }\end{array}$ \\
\hline Sciurus aestuans & 0.16 & & & & & \\
\hline Oxymycterus sp. & 0.33 & 0.23 & & & & \\
\hline Oryzomys russatus & 0.14 & 0.09 & 0.11 & & & \\
\hline Nectomys squamipes & 0.12 & 0.08 & 0.20 & 0.14 & & \\
\hline Didelphis aurita & - & - & - & - & - & \\
\hline Marmosops incanus & 0.08 & - & - & 0.25 & - & - \\
\hline
\end{tabular}

were restricted to only one host species and, on the other hand, four ectoparasite taxa (Listrophoridae, Macronyssidae, A. fahrenholzi and Ixodes sp.) were also very frequent but were distributed on two, or more host species. In this cases the analyze of the MA showed a high association to one host species. The fleas $P$. (P.) r. roberti and $P$. (P.) rimatus occurred at low frequencies but also were associated with at least two host species.

The Jaccard's index showed a low value of similarity across the ectoparasite community. The only exception from this pattern of extreme host specificity occurred with P. iheringi and Oxymycterus sp., which shared five species of ectoparasites. However, the macronyssid and listrophorid mites, as well as cheyletid, could not be identified to the specific level due to the limited knowledge of the group. These taxonomic problems may have led to the production of a false cluster for macronyssid and listrophorid. In spite of these facts, the similarity values, for most of the cases, is smaller than 0.2 .

The complex life cycle of ticks, in which larvae, nymphs and adult forms may parasitize individual hosts of different species (Lopes et al. 1998) may result in larvas and nymphs of Ixodes sp. to be largely distributed in different host species. Immature forms of ticks have already been reported to feed on more than 300 host species (Oliver Jr 1989). On the other hand, I. didelphidis is considered a host-specific tick. There are 29 records of this species in the Ixodides collection of Aragão deposited in the Fundação Oswaldo Cruz (all of them from the state of Goiás and of the year of 1936). This is one of the few available sources of information on this species. Of these records only three hosts are not marsupials and of the remaining 26 records, 18 are of the genus Didelphis.

The laelapine mites usually have specific associations with their host species. Two species of the genus Tur were the most frequent in the study and occurred exclusively on $P$. iheringi. The close association between Tur spp. and rodents of the family Echimyidae was noted by Furman (1972) and has been corroborated in several different studies (e.g. Botelho \& Williams 1980, Linardi et al. 1991a). Similarly, G. goyanensis, G. oudemansi and L. manguinhosi were strictly host specific. Mites identified as $A$. marmosops were represented by only two individuals is the new species described by Martins-Hatano et al. (2001) from the same host species at Ilha Grande and Itatiaia (both in the state of Rio de Janeiro). The laelapine
A. fahrenholzi had the most generalist association in the present study, occurring in all rodent host species captured. Barros-Battesti et al. (1998) reported a similar association, with six of eight species of mammalian hosts studied parasitized with $A$. fahrenholzi. Similar associations have been observed in another studies (e.g. Botelho \& Linardi 1996, Lareschi 1996). Furman (1972) noted that $A$. fahrenholzi may not be a single species, but a complex of species. Despite of the marked specificity found in our data, other studies have shown that laelapine mites often share different host species (e.g. Botelho \& Williams 1980, Botelho et al. 1981, Linardi et al. 1984, Guitton et al. 1986). Furman (1972) reported that laelapine mites were often associated with hosts at a higher taxonomic level (genus, family).

Many fleas utilize an intermediate strategy between total specificity and generalization. In Brazil, several studies describe different host species being shared by a particular flea species (e.g. Linardi et al. 1984, 1991a, c, Guitton et al. 1986, Botelho \& Linardi 1996, Carvalho et al. 2001) and others provide calculations of the "true host" (Botelho et al. 1981, Barros-Battesti et al. 1998). Because fleas are important vectors of plague, exchange of fleas between wild and domestic rodent hosts can be important in the maintenance of epizootics and zoonoses (Carvalho et al. 2001).

Were collected five species of monoxenic, and two of polyxenous fleas. Polygenis (P.) r. roberti had the widest distribution among the flea species in this study. From data on host-parasite relationships obtained in the available literature, Linardi and Guimarães (2000) mention the genus Oryzomys as the main host (46\% of the cases) of $P$. (P.) r. roberti. Because in our study only three specimens of $O$. russatus are collected, none of this flea was found in this host. Also, Guitton et al. (1986), working on Ilha Grande, reported $P$. (P.) r. roberti predominantly from hosts of the genus Oryzomys (54.4\%). Another flea species which is known to occur on more than one host species is $P$. (P.) rimatus. Linardi and Guimarães (2000) point out as the main hosts for this flea are rodents of the genera Akodon and Oryzomys. Since species of Akodon were not found in Ilha Grande and few specimens of $O$. russatus were collected, in the present study, $P$. (P.) rimatus occurred on $P$. iheringi, $S$. aestuans and Oxymycterus sp. However, only one specimen was collected from a recaptured individual of $P$. iheringi, where 
as on individuals of the genus Oxymycterus, this flea species represented the largest relative density of all the siphonapterans.

Within fleas the monoxenic cycle $P$. (P.) o. occidentalis is considered as rare, representing less than a percent of the collections (Linardi \& Guimarães 2000). Even so, those authors describe the presence of this flea in mammals (Rodentia, Marsupialia, Carnivora and Edentata), and birds. In the present study this flea species was the most frequent and specific. Hechtiella lakoi is restricted to the Atlantic Forest Biome, having as main host $P$. iheringi (Linardi \& Guimarães 2000), which also occurred in our study. P. (P.) tripus was widely distributed among host species, as well as in geographical regions (Linardi \& Guimarães 2000). In our study, only one individual of that species was collected from a recaptured individual of $S$. aestuans.

References on the specific relationships between ectoparasites and host species are frequent for the lice of the suborders Amblycera (Emerson \& Price 1981) and Anoplura (Johnson 1972, Durden \& Musser 1994a, b). However, this relationship is still poorly known in Brazil. The sucking louse $H$. sciuricola is considered as a species with a low degree of specificity, parasitizing different species of the family Sciuridae, mainly of the genus Sciurus (Johnson 1972, Durden \& Musser 1994a). In this study $H$. sciuricola was collected exclusively on $S$. aestuans. Durden and Musser $(1994 \mathrm{a}, \mathrm{b})$ list $P$. iheringi as the specific host of $P$. wernecki, being this pattern also now observed. Polyplax spinulosa, which in our study was restricted to S. aestuans, is indicated as a parasite of cosmopolitan distribution (Durden \& Musser 1994b), occurring mainly on species of the genus Rattus. In Brazil, it is associated primarily with $R$. norvegicus (e.g. Linardi et al. 1987, Botelho \& Linardi 1996), R. rattus and A. cursor (Oliveira et al. 2001).

$P$. iheringi was the only host of chewing lice in this study. Guitton et al. (1986) present three species collected on Proechimys [Gyropus lineatus, Gliricola porcelli, and Trimenopon jenningsi (Kellogg \& Paine, 1916)] and Cavia [Gyropus ovalis Burmeister, 1838, G. porcelli, and T. jenningsi]. The shared species present a considerable difference in the distribution: G. porcelli on Proechimys (83.3\%) and T. jenningsi on Cavia (96\%).

The beetles Amblyopinus sp. and Amblyopinodes sp. now are recognized as mutualists and non-parasites (Ashe $\&$ Timm 1987). The species of that group are primarily associated with South American cricetid and caviomorph rodents, and marsupials, and there is consistent evidence of host specificity (Ashe \& Timm 1995). The occurrence of these two beetle species associated to rodent species of distinct taxonomic groups seems to affirm that fact.

We conclude that the species of the ectoparasite community associated with small mammals on Ilha Grande are relatively specific, resulting in a composition of ectoparasite species particular to each host species.

\section{ACKNOWLEDGEMENTS}

To Coordination of the Ceads/Uerj, the Direction of Campi Regionais, and the Administrative Coordination for local support and many facilities available. To CF Vera-Conde for assistance in the field work. To the specialists that helped us identify the ectoparasites and the small mammals: mites - Drs JR Botelho of the UFMG, and D Gettinger of the University of Central Arkansas; ticks - Drs GS Gazêta, M Amorim, and NM SerraFreire all of the Fiocruz; fleas - Dr RW Carvalho of the Fiocruz; lice - Drs PM Linardi of the UFMG, and PB Ribeiro of the UFPel; beetles - Dr LG Santos Neto of the UFPR; P. iheringi Dr L Pessôa of the UFRJ and the other mammals - Dr L Geise of the Uerj. To D Gettinger, HG Bergallo, L Geise, M Van Sluys and MAS Alves for suggestions on a previous version of the study. HG Bergallo helped in many aspects along the study.

\section{REFERENCES}

Araujo DSD, Oliveira RR 1988. Reserva Biológica Estadual da Praia do Sul (Ilha Grande, estado do Rio de Janeiro): Lista preliminar da flora. Acta Bot Bras 1: 83-94.

Ashe JS, Timm RM 1987. Probable mutualistic association between staphylinid beetle (Amblyopinus) and their rodent host. J Trop Ecol 3: 177-181.

Ashe JS, Timm RM 1995. Systematics, distribution, and host specificity of Amblyopinus Solsky 1875 (Coleoptera Staphylinidae) in Mexico and Central America. Trop Zool 8: 373-399.

Barker SC 1994. Phylogeny and classification, origens, and evolution of host associations of lice. Int J Parasitol 24: 1285-1291.

Barros-Battesti DM, Arzua M, Linardi PM, Botelho JR, Sbalqueiro IJ 1998. Interrelationship between ectoparasites and wild rodents from Tijucas do Sul, state of Paraná, Brazil. Mem Inst Oswaldo Cruz 93: 719-725.

Bossi DEP 1996. Ectoparasitismo em Pequenos Mamíferos da Estação Ecológica de Juréia-Itatins, Iguape (SP), MSc Thesis, Unicamp, Campinas, Brasil, 89 pp.

Botelho JR, Linardi PM 1980. Alguns ectoparasitos de roedores silvestres do município de Caratinga, Minas Gerais, Brasil. I. Relação pulga/hospedeiro. Rev Brasil Ent 24: 127-130.

Botelho JR, Linardi PM 1996. Interações entre ectoparasitos e roedores em ambientes silvestre e urbano de Belo Horizonte, Minas Gerais, Brasil. Rev Brasil Ent 40: 425-430.

Botelho JR, Williams P 1980. Sobre alguns ectoparasitos de roedores silvestres do município de Caratinga, Minas Gerais, Brasil. II. Acarofauna. Mem Inst Oswaldo Cruz 75: 47-51.

Botelho JR, Linardi PM, Williams P, Nagem RL 1981. Alguns hospedeiros reais de ectoparasitos do município de $\mathrm{Ca}$ ratinga, Minas Gerais, Brasil. Mem Inst Oswaldo Cruz 76: 57-59.

Bush AO, Lafferty KD, Lotz JM, Shostak AW 1997. Parasitology meets ecology on its own terms: Margolis et al. Revisited. J Parasitol 83: 575-583.

Carvalho WC, Serra-Freire NM, Linardi PM, Almeida AB, Costa JN 2001. Small rodents fleas from the bubonic plague focus located in the Serra dos Órgãos mountain range, State of Rio de Janeiro, Brazil. Mem Inst Oswaldo Cruz 96: 603-609.

Cerqueira EJL, Linardi PM 1981. Relações hospedeiro/parasito em Polygenis tripus (Siphonaptera, Rhopalopsyllidae). Bol Mus Hist Nat 24: 1-11.

Durden LA, Musser GG 1994a. The mammals hosts of the sucking lice (Anoplura) of the world: a host-parasite list. Bull Soc Vetor Ecol 19: 130-168.

Durden LA, Musser GG 1994b. The sucking lice (Insecta: Anoplura) of the world: a taxonomic checklist with records of mammaliam hosts and geografical distributions. Bull Am Mus Nat History 218: 1-90.

Emerson KC, Price RD 1981. A host-parasite list of the Mallophaga on mammals. Misc Publ Entomol Soc Am 12: $1-72$. 
Furman DP 1972. Laelapid mites (Laelapidae: Laelapinae) of Venezuela. Brigham Young Univ Sci Bull 17: 1-57.

Gettinger D 1987. Host associations of Gigantolaelaps (Acari: Laelapidae) in the Cerrado Province of central Brazil. J Med Entomol 24: 559-565.

Gettinger D 1992a. Three new species of Laelaps (Acari: Laelapidae) associated with small mammals in central Brazil. J Med Entomol 29: 66-70.

Gettinger D 1992b. Host specificity of Laelaps (Acari: Laelapidae) in central Brazil. J Med Entomol 29: 71-77.

Gettinger D, Ernest KA 1995. Small-mammal community structure and the specificity of ectoparasite associations in central Brazil. Rev Bras Biol 55: 331-341.

Guitton N, Araujo-Filho NA, Sherlock IA 1986. Ectoparasitas de roedores e marsupiais no ambiente silvestre de Ilha Grande, estado do Rio de Janeiro, Brasil. Mem Inst Oswaldo Cruz 81: 233-234.

Holland GP 1964. Evolution, classification and host relationships of Siphonaptera. Ann Rev Ent 9: 123-146.

Johnson PT 1972. Sucking lice of Venezuelan rodents, with remarks on related species (Anoplura). Brigham Young Univ Sci Bull 17: 1-62.

Klompen JSH, Blackiv WC, Keirans JE, Oliver JR JH 1996. Evolution of ticks. Annu Rev Entomol 41: 141-161.

Lareschi M 1996. Estudio preliminar de la comunidad de roedores (Rodentia: Muridae) y sus ectoparasitos (Acari, Phthiraptera y Siphonaptera) em Punta Lara (Buenos Aires). Rev Soc Entomol Argent 55: 113-120.

Linardi PM 1977. Relações pulgas/roedores observados nos municípios de Salesópolis e Itapetininga, SP. Bol Mus Hist Nat 23: 1-23.

Linardi PM, Guimarães LR 2000. Sifonápteros do Brasil, Museu de Zoologia USP/Fapesp, São Paulo, 291 pp.

Linardi PM, Botelho JR, Ximenez A, Padovani CR 1991c. Notes on ectoparasites of some small mammals from Santa Catarina state, Brazil. J Med Entomol 28: 183-185.

Linardi PM, Botelho JR, Neves DF, Cunha HC 1984. Sobre alguns ectoparasitos de roedores silvestres de Belo Horizonte, MG. Rev Bras Biol 44: 215-219.
Linardi PM, Botelho JR, Rafael JA, Valle CMC, Cunha A, Machado PAR 1991a. Ectoparasitos de pequenos mamíferos da Ilha de Maracá, Roraima, Brasil. I. Ectoparasitofauna, registros geográficos e de hospedeiros. Acta Amazonica 21: 131-140.

Linardi PM, Botelho JR, Rafael JA 1991b. Ectoparasitos de pequenos mamíferos da Ilha de Maracá, Roraima, Brasil. II. Interação entre ectoparasitos e hospedeiros. Acta Amazonica 21: 141-150.

Linardi PM, Teixeira VP, Botelho JR, Ribeiro LS 1987. Ectoparasitos de roedores em ambientes silvestres do município de Juiz de Fora, Minas Gerais. Mem Inst Oswaldo Cruz 82: 137-139.

Lopes CML, Leite RC, Labruna MB, Oliveira PR, Borges LMF, Rodrigues ZB, Carvalho HA, Freitas CMV, Vieira Jr CR 1998. Host Specificity of Amblyomma cajennense (Fabricius, 1787) (Acari: Ixodidae) with comments on the drop-off rhythm. Mem Inst Oswaldo Cruz 93: 347-351.

Magurran AE 1988. Ecological Diversity and its Measurement, Croom Helm Ltd, London, 179 pp.

Martins-Hatano F, Gettinger D, Bergallo HG 2001. Androlaelaps marmosops (Acari: Laelapidae) a new species associated with the mouse opossum Marmosops incanus (Lund, 1840) in the Atlantic Forest of Rio de Janeiro state, Brazil. Rev Bras Biol 61: 685-688.

Martins-Hatano F, Gettinger D, Bergallo HG 2002. Ecology and host specificity of laelapine mites (Acari: Laelapidae) of small mammals in an Atlantic Forest area of Brazil. $J$ Parasitol 88: 36-40.

Oliveira HH, Almeida AB, Carvalho RW, Serra-Freire NM 2001. Anopluros de roedores dos focos pestígenos da Serra dos Órgãos, municípios de Nova Friburgo, Teresópolis e Sumidouro, estado do Rio de Janeiro, Brasil. Entomol Vect 8: 229-243.

Oliver Jr. JH 1989. Biology and systematics of ticks (Acari: Ixodida). Ann Rev Ecol Syst 20 397-430.

Timm RM 1983. Fahrenholz's rule and resource tracking: a study of host-parasite coevolution. In MN Nitecki, Coevolution, University of Chicago Press, Chicago, p. 225-265. 